\title{
THE ROLE OF CITY SOILS IN THE SUSTAINABLE DEVELOPMENT OF MEGAPOLIS: RUSSIAN AND FOREIGN EXPERIENCE OF CREATION AND MAINTENANCE
}

\author{
Marina Vakula \\ Ass. Prof., RUDN University, RUSSIA, vakula2004@yandex.ru
}

\begin{abstract}
Sustainable development of society is the achievement of a balance between economic and social development, as well as environmental protection. Its main principle is the most rational use of resources with the least negative impact on the environment and even its complete absence. Such a goal is somewhat utopian, but it is an effective deterrent.

The highest role in the development of society is given to cities. According to UN forecasts, as early as 2050, about $2 / 3$ of the world's population will live in urban areas. It should be remembered that with an increase in population, it is necessary to increase the volume of infrastructure, affordable housing, and production, spending additional energy and resources. Besides, cities are centers of industry and manufacturing, points of formation of a considerable amount of waste, emissions, and discharges. The world community is concerned that urban activities are leading to climate change and the disruption of natural processes.

That is why the achievement of sustainable urban development is one of the priority tasks of modern society. In this article, the author analyzes the possibilities of reducing adverse effects by creating greened protective areas that are resistant to the urban environment. The author also offers regulatory suggestions for taking into account soil features when creating new landscaping facilities, establishing regulatory requirements for soil quality indicators that ensure germination, development of green spaces, and maintenance of green areas taking into account optimal environmental and economic indicators.
\end{abstract}

The goal of this study will be achieved by performing the following tasks:

- The study of international and Russian experience in ensuring the sustainable development of cities concerning the protection of urban soils;

- The application of the results of international studies to the existing regulatory legal requirements in Russia for the creation and maintenance of green areas in megacities;

The methodological base of the research is constituted by such general scientific methods as dialectical and systemic research methods, analysis, synthesis, induction, deduction, analogy, and alike, and such specific scientific methods as historical and legal research, comparative legal research, formal legal, structuralfunctional and statistical methods. The study is based on the results of studies conducted by Russian and foreign lawyers, ecologists, biologists, as well as economists related to the research topic.

The results of the study can be used for effective environmentally-friendly planning and construction of megacities for countries with similar problems in the field of minimizing the impact of urban activities on climate change and disruption of natural processes.

Keywords: sustainable development of megapolis, urban areas, urban soils, creation of green spaces.

\section{INTRODUCTION}

Urban soils are an important factor in the process of providing an ecologically clean environment for the life of the urban population. Therefore, ensuring a high-quality environment in a megalopolis, including by 
preventing soil and land degradation, it has been declared one of the priority goals of ensuring environmental safety in Russia and is an integral part of the urban planning policy of Russian cities to provide the population with a full range of ecosystem services.

Under the conditions of extensive housing and road construction, and the activity of industrial enterprises, a significant part of urban soils is being covered with waterproof hard coatings or built-up with buildings and structures. Besides, it should be noted a significant negative of impact of emissions from vehicles and industry on soils.

Due to the significant influx of pollutants from natural environments adjacent to soils, its ability in the remaining territories to self-healing, maintaining natural bio-geneses and the implementation of natural ecological functions is sharply reduced. The consequence of these processes is a decrease in the quality and comfort of the urban environment for the living of the population, as well as failure to achieve one of the priority goals of modern society - the sustainable development of the urbanized area.

\section{METHODOLOGY}

Activities to create a favorable urban environment and reduce adverse anthropogenic effects through the creation of greening protective areas that are resistant to the urban environment are impossible without creating an appropriate regulatory framework. The basis of legal regulation is constitutional norms (part 1 of Art. 9, Art. 42, and other of the Constitution of Russia, as well as Land legislation, legislation in the field of environmental protection, urban planning, and other normative acts).

At the same time, special attention should be paid to regulatory acts of the regional level, which are aimed at ensuring the sustainable development of territories. In particular, sufficiently developed legislation in the Russian Federation in this area has the northernmost metropolis - the city of Moscow.

The Moscow Law on the Master Plan of the city of Moscow contains the leading indicators for the development of specially protected natural areas, natural and green spaces in the 2025 perspective. The analysis of these indicators reflects the intention of the city authorities to increase the provision of the population with green areas of general use to $6.6 \%$ (7.1 thousand hectares) of the total area of the city.

At the same time, landscaping is the essential element of the comprehensive improvement and landscape organization of the territory, ensuring the formation of an urban environment with the active use of plant components, as well as maintaining a previously created or initially existing natural environment in the city.

Relations related to the landscaping, maintenance, and protection of green spaces are regulated by the Law of the City of Moscow on Improvement, as well as other regulatory legal acts of the Russian Federation, laws and other regulatory legal statutes of the city of Moscow on landscaping, maintenance, and protection of green spaces.

Moscow's environmental strategy sets goals to increase the area of green spaces from $54.5 \%$ to $61 \%$ by 2030. In total, about six million trees and shrubs were planted in Moscow in yards, parks, boulevards, squares and on the city streets from 2011 to 2018, including more than 107 thousand trees as part of compensatory plantings of green spaces - in exchange for those lost due to abnormal weather conditions.

However, the creation and operation of landscaping facilities cannot be carried out without establishing and unconditionally fulfilling the requirements for soil quality. Soil quality standards on the lands of settlements are adopted at the level of hygiene standards, which are designed, first of all, to ensure safety for humans. However, as a rule, in urban areas of general use, as well as in residential, industrial construction sites, plants intended for feeding the population are not grown. Based on this, it seems necessary to develop and implement quality standards for urban soils that ensure normative germination, development of green spaces, and maintenance of green areas, taking into account optimal environmental and economic indicators, using international experience in the protection of urban soils.

\section{RESULTS}

\subsection{Legal Regulation of the Quality of Urban Soils in the Russian Federation}

In Russia, the established standards for soil quality upon chemical indicators - threshold limit value - (TLV) are the same for all soils, regardless of their type, properties, or composition; when establishing the standards, the soil resistance to absorption of chemicals was not taken into account, the standards are not differentiated taking into account the climatic features of the territory of the Russian Federation.

For individual chemicals, TLVs are not established for all forms of being in the soil. Soil quality standards have not been developed for several essential substances, including oil products and individual oil fractions. 
There are no approved standards for the permissible content of radioactive isotopes in elemental form and the form of compounds.

To assess the quality of the soils of settlements upon chemicals of non-natural origin, hygienic standards are subject to application. At the same time, the establishment of environmental regulation of soils for the lands of settlements in exclusive connection with sanitary and epidemiological supervision does not provide for fixing requirements for the used soil mixtures in terms of indicators of soil fertility. This, in turn, negatively affects the quality of urban green spaces and leads to unjustified budget expenditures: recently, the city has spent about 10 billion Roubles annually on the organization of parks, the creation, and improvement of green areas.

The recently approved Rules for Conducting Land Remediation and Conservation did not clarify these issues: according to Clause 5 of the Rules, land remediation must ensure the restoration of land to a state suitable for its use under its intended purpose and permitted use, by ensuring that the land quality complies with environmental quality standards and the requirements of the legislation of the Russian Federation in the field of ensuring sanitary and epidemiological welfare of the population. At the same time, it should be noted that the normative consolidation of the mandatory compliance of land quality with environmental quality standards is enshrined in a particular act on land remediation for the first time.

\subsection{Legal Regulation of the Quality of Urban Soils Abroad}

Since the beginning of 2000, Decisions of the European Commission began to have a significant impact on law-making and the policies of EU member states. The European Community Communication Directive No. 179 , adopted in 2002, stipulated that actions in the field of production and consumption waste disposal, protection of water and air, climate change, safety in the use of hazardous substances, floods, biological diversity, and environmental responsibility should also take into account protection of soil from degradation and pollution. This was the first directive in which the European Commission addressed the soil protection issues directly. The importance of regulation in this area is emphasized by the fact that only nine member states of the European Community had, at that time specific legislation in the field of soil protection (especially soil pollution) based on different approaches.

Later in 2004, another significant European Commission Directive No. 2004/35 / EC on environmental responsibility, was adopted, which introduced general concepts of liability, applicable to all members of the European Community in cases where soil pollution poses a significant risk to human health. However, this directive did not address cases of soil pollution in the past, i.e., those that occurred before the entry into force of the directive.

The Sixth Environmental Action Program (6th EAP) was also adopted in 2002 and is valid through 2012. This program requires the European Commission to prepare Thematic Strategies in seven priority areas. These strategies defined a long-term perspective and set clear environmental goals for the period until approximately 2020, thus ensuring the sustainable development of the countries of the European Union. Their task is also to identify appropriate management tools to fulfil environmental goals in the most efficient (least costly) way.

The comprehensive Soil Protection Strategy, adopted in September 2006, calls for considering the soil a conditionally "non-renewable" resource since the soil has been forming over a long period and therefore needs special conservation measures. According to a rough estimate of the European Commission, in the EU countries, about 115 million hectares or $12 \%$ of the European Union are subject to water erosion, 42 million hectares are subject to wind erosion, about $45 \%$ of European soils have low organic matter (mainly in southern Europe, but also some areas of France, the UK, and Germany), the area of potentially contaminated sites is estimated at approximately 3.5 million hectares. Based on an analysis of recent years, it is expected that soil degradation may further intensify. It is noted that mainly the society as a whole suffers the damage from the soil and land degradation, and not specific landowners.

It seems advisable to turn to legislation in the field of soil protection in Germany, which within a reasonably short time created an effective legal regulation in this area, as well as implemented a broad range of remediation work to restore contaminated territories and create sustainable landscaping facilities in the urbanized territory.

In modern German law, the primary legal regulations for soil are concentrated in the Federal Law on Soil Protection (Gesetz zum Schutz vor schädlichen Bodenveränderungen und zur Sanierung von Altlasten). This law includes both general conditions for the protection of soils and the most essential provisions defining the obligations of the state and land users in the field of soil protection, prevention of soil and groundwater pollution, the procedure for regenerating soil covered with coatings, the deposition of various substances and 
materials into the soil; it establishes standardized soil quality criteria, and the process for issuing additional guidelines in the areas of law, set by law (for example, the introduction of quotas for "sealed" soil coatings), administration in the field of complementary legislation and standardization of soil protection.

The most crucial regulation supplementing the Soil Protection Act is the Soil Protection and Pollution Protection Ordinance (Bundes-Bodenschutz und Altlastenverordung), which replaced or increased the soil protection conditions outlined in various earlier laws and other legal acts. The last decree is the technical regulation, the primary tool that ensures the application of the Law on Soil Protection in Germany. The Decree specifies the procedure for conducting studies to assess the risk of soil pollution, establishes requirements for sampling, methods for conducting chemical analyses and quality control of work; measures to prevent soil degradation; determines the maximum and relatively acceptable concentrations of pollutants in soils.

In addition to federal legislation, most federal states have issued their laws and procedural instructions for the protection of soils. They include rules for providing access to land for research, the procedure for registration and restrictions on the use of contaminated sites, the creation of databases, and others.

\section{CONCLUSIONS}

The soils of settlements must necessarily correspond to quality indicators that ensure normative germination, development of green spaces, and maintenance of green areas, taking into account optimal environmental and economic indicators as one of the ways to achieve this can become the change in the regulatory framework governing green construction by establishing quality standards for urban soils, taking into account fertility indicators. In its turn, it requires fixing in the methodology for calculating the soil quality standards for soil zoning as the basis for the survival of green spaces, as well as fixing requirements for controlling soil quality as an element of a favorable environment for the population and achieving sustainable urban development.

In the framework of harmonization of the Russian environmental legislation with the legislation of the EU at the regional level, the author can give examples of the above Moscow regulatory legal acts in the field of protection of green spaces and soil protection. In particular, in specific approaches, the rules for the creation, maintenance, and protection of green spaces and natural communities operating in Moscow are similar to the decree adopted in Germany. It seems that the capital's experience in developing environmental legislation can be used both in other regions of the Russian Federation and in other countries facing environmental challenges arising in densely populated areas.

An analysis of the Russian and national experience of European countries with dense urban development, as well as the significant negative impact of the transport system, allows us to justifiably assume the need to consolidate the relevant requirements for agricultural activities aimed at improving fertility and protecting urban soils within the framework of the country's regional legislation. At the same time, it is necessary to clarify the requirements governing the creation and maintenance of landscaping facilities (at the state and municipal levels), as well as to specify the criteria for the examination of the soils of the created green areas in the acceptance procedures for the accomplished works. Norms are required in the legislation governing urban development in terms of securing mandatory requirements for the creation of landscaping of territories along the highway in areas of dense residential development, needs for a minimum area of landscaping in cities, as well as requirements for the quality of landscaping of the residential regions, sanitary protection zones, and other similar territories.

\section{ACKNOWLEDGMENT}

The publication has been prepared with the financial support of the «RUDN University Program 5-100».

\section{REFERENCE LIST}

Bundes-Bodenschutz und Altlastenverordung. (BBodSchV). Datum: 12. Juli 1999 (BGBI. I S. 1554), geändert durch Artikel 2 der Verordnung vom 23. Dezember 2004 (BGBI. I S. 3758); Stand: Geändert durch Art. 2 V v. 23.12.2004 I 3758.

Communication from the Commission of the Council, the European Parliament, the Economic and Social Committee and the Committee of the Regions. Thematic Strategy for Soil Protection. Brussels, 22.9.2006 COM (2006)231 final.

Directive 2004/35/EC (OJ L 143, 30.4.2004, p. 56) 
Gesetz zum Schutz vor schädlichen Bodenveränderungen und zur Sanierung von Altlasten. (BBodSchG). Datum: 17. März 1998; Fundstelle: BGBI I 1998, 502; Textnachweis ab: 1. 3.1999; Stand: Zuletzt geändert durch Art. 3 G v. 9.12.2004 I 3214.

The Sixth Environment Action Programme of the European Community 2002-2012.

Towards a thematic strategy on Soil Protection. Communication from the Commission of the Council, the European Parliament, the Economic and Social Committee and the Committee of the Regions. Brussel 16.04.2002. COM(2002)179.

Verordnung über die Eintragung des Bodenschutzlastvermerks. Datum: Vom 18. März 1999. (BGBI. I 1999 S. 497).

The Law of Moscow of 05.05.2010 N 17 (as amended on 12/27/2017) "On the General Plan of the City of Moscow" // "Tverskaya 13", N 67, 06/03/

The law of Moscow of 30.04.2014 N 18 (as amended on 05/17/2018) "On improvement in the city of Moscow" // "Tverskaya, 13", N 67-68, 06/05/2014

Law of the city of Moscow dated September 26, 2001 No. 48 "On Specially Protected Natural Territories in the City of Moscow".

The law of the city of Moscow dated 02.03.2005 No. 9 "On integrated environmental management in the city of Moscow".

The law of the city of Moscow dated 04.07.2007 No. 31 "On urban soils".

The law of the city of Moscow dated 05.05.1999 No. 17 "On the protection of green spaces".

The law of the city of Moscow dated 06.07.2005 No. 37 "On the scheme for the development and deployment of specially protected natural territories in the city of Moscow".

Law of the city of Moscow dated 20.10.2004 No. 65 "On environmental monitoring in the city of Moscow".

Law of the city of Moscow dated November 21, 2007 No. 45 "Code of the City of Moscow on Administrative Offenses".

Ivashchuk, I.S. (2011) Soils as an object of legal protection // Environmental Law. No. 6.

The Constitution of the Russian Federation. (1993) Adopted by popular vote on December 12, 1993, // Ros. gas. N 237. 12 Dec.

Melnik, L.A. (2006) Legal protection of soils: Dissert. Thesis, Moscow.

Minina, E.L. Legal protection of soils in cities // Legal support of a favorable environment in cities: Scientific and practical manual.

Decree of the Government of the Russian Federation of February 13, 2019 No. 149 "On the development, establishment, and revision of environmental quality standards for chemical and physical indicators of the state of the environment, as well as on the approval of regulatory documents in the field of environmental protection, establishing technological indicators of the best available technology."

Decree of the Government of the Russian Federation of July 10, 2018 N 800 (as amended on March 7, 2019) "On the implementation of land restoration and conservation" // "Collection of the legislation of the Russian Federation", July 16, 2018, No. 29, art. 4441.

Decree of the Moscow Government dated 10.07.2014 No. 394-PP (as amended on 11/22/2016) "On the main provisions of the new environmental policy of the city of Moscow for the period until 2030" // "Bulletin of the Mayor and the Government of Moscow", N 39, 15.07.2014

Resolution of the Moscow Government of September 10, 2002, No. 743-PP (as amended on September 3 , 2019) "On the Approval of the Rules for the Creation, Maintenance and Protection of Green Plants and Natural Communities of the City of Moscow" // Bulletin of the Mayor and the Government of Moscow, No. 51, November 2002.

Bogolyubov, S.A. Boltanova, E.S. Vypkhanova, G.V. et al.; (2013) open ed. N.V. Kichigin. Moscow: IZISP RF: INFRA-M.

Decree of the President of the Russian Federation of April 19, 2017 No. 176 "On the Strategy for the Environmental Safety of the Russian Federation for the period until 2025" 